\title{
Erratum to: Social Crowd Integration in New Product Development: Crowdsourcing Communities Nourish the Open Innovation Paradigm
}

\author{
Andreas Mladenow • Christine Bauer • \\ Christine Strauss
}

Published online: 5 February 2014

(C) Global Institute of Flexible Systems Management 2014

\section{Erratum to: Global Journal of Flexible Systems} Management

DOI 10.1007/s40171-013-0053-6

In the original publication of this article, affiliation of Christine Bauer has been mentioned incorrectly. The correct affiliation is given in this erratum.

The online version of the original article can be found under doi:10.1007/s40171-013-0053-6.

A. Mladenow $(\varangle) \cdot$ C. Strauss

Department of e-Business, School of Business, Economics and

Statistics, University of Vienna, Oskar Morgenstern Platz 1,

1090 Vienna, Austria

e-mail: andreas.mladenow@univie.ac.at

C. Strauss

e-mail: christine.strauss@univie.ac.at

C. Bauer

Department of Information Systems \& Operations, Vienna

University of Economics and Business, Welthandelsplatz 1, D2,

1020 Vienna, Austria

e-mail: chris.bauer@wu.ac.at 